\title{
Uptake Patterns of Untreated Primary Gastrointestinal Extranodal Lymphomas on Initial Staging I8F-FDG PET/CT and Metabolic Tumor Parameters
}

\author{
Primer Ekstranodal Gastrointestinal Sistem Lenfomalarında Primer Evreleme I8F-FDG PET/ \\ BT'de Tutulum Paternleri ve Metabolik Tümör Parametreleri
}

\author{
Engin Alagözl, Kürşat Okuyucul', Semra Incel, Murat Kantarcıoğlu², Şükrü Özaydın³, Cumhur Heper4, Türker Türker5, Nuri Arslan' \\ ' Gülhane Training and Research Hospital, Clinic of Nuclear Medicine, Ankara, Turkey \\ 2Gülhane Training and Research Hospital, Clinic of Gastroenterology, Ankara, Turkey \\ ${ }^{3}$ Gülhane Training and Research Hospital, Clinic of Medical Oncology, Ankara, Turkey \\ ${ }^{4}$ Istanbul University Institute of Cardiology, Clinic of Nuclear Medicine, Istanbul, Turkey \\ ${ }^{5}$ Gülhane Training and Research Hospital, Clinic of Public Health, Ankara, Turkey
}

\begin{abstract}
Objective: Non-Hodgkin's lymphomas arising from tissues other than primary lymphatic sites are classified as primary extranodal lymphomas (PEL). PELs of the gastrointestinal system (PGISL) originate from the lymphatic tissues within the gastrointestinal tract. The prognostic value of 18F-FDG PET/CT in lymphomas is high in terms of both overall survival (OS) and disease-free survival (DFS). Our aim was to investigate the uptake patterns and properties of low-grade and high-grade PGISL on primary staging 18F-FDG PET/CT, as well as the prognostic significance of metabolic tumor parameters in high grade PGISL. Methods: Thirty-nine patients with PGISL were enrolled in this retrospective cohort study between 2004-2015. Primary staging 18F-FDG PET/CT have been performed and quantitative parameters of SUV max, SUV mean, metabolic tumor volume (MTV), total lesion glycolysis (TLG) have been calculated for all patients prior to treatment. Low-grade and high-grade PGISL were compared in terms of metabolic tumor parameters. Cox regression models were performed to determine factors that correlate with DFS in high-grade PGISL.

Results: There were statistically significant differences between high-grade and low-grade PGISL in terms of SUV max, SUV $V_{\text {mean }}$ MTV, TLG, recurrence, mortality, DFS and OS. None of the potential risk factors (sex, age, site, SUV max $_{\text {, SUV }}$ mean, MTV, TLG) for recurrence and metastasis in high grade PGISL was identified as a risk factor on univariate and multivariate Cox regression analysis.

Conclusion: Metabolic tumor parameters are not predictive markers in high-grade PGISL, especially in diffuse large B cell variant and primary gastric lymphoma. The first implications suggest they will not play a role in patient management.

Keywords: 18 F-fluorodeoxyglucose positron emission tomography/computed tomography, metabolic tumor parameters, primary gastrointestinal lymphoma
\end{abstract}

Address for Correspondence: Engin Alagöz MD, Gülhane Training and Research Hospital, Clinic of Nuclear Medicine, Ankara, Turkey Phone: +90 5425779101 E-mail: enalamed@yahoo.com ORCID ID: orcid.org/0000-0002-4214-4016 Received: 28.03.2017 Accepted: 07.06.2017 


\section{Öz}

Amaç: Primer lenfatik alanlar dışındaki dokulardan kaynaklanan Non-Hodgkin lenfomalara primer ekstranodal lenfoma (PEL) denmektedir. Gastrointestinal sistemin PEL'i (PGISL) buradaki lenfatik dokulardan köken alır. 18F-FDG PET/BT lenfomalarda genel ve hastalıksız sağkalım açısından yüksek prognostik değere sahiptir. Amacımız düşük grad ve yüksek grad PGISL'de primer evreleme 18F-FDG PET/BT'de tutulum şekillerini, özelliklerini, yüksek grad PGISL'de metabolik tümör parametrelerinin prognostik önemi ile birlikte araştırmaktır.

Yöntem: 2004-2015 yılları arasında PGISL (evre 1-2) tanısı konmuş 39 hasta bu retrospektif kohort çalışmaya dahil edildi. Hastalara tedaviden önce primer evreleme 18 F-FDG PET/BT çekilmiş ve maksimum standardize uptake değeri (SUV maks $_{\text {), }}$ ortalama standardize uptake değeri (SUV ortalama), metabolik tümör hacmi (MTV) ve total lezyon glikolizi (TLG) gibi metabolik tümör parametreleri hesaplanmıştı. Düşük grad ve yüksek grad PGISL metabolik tümör parametreleri açısından karşılaştıııldı. Yüksek grad PGISL'de Cox regresyon modelleri üzerinden hastalıksız sağkalım ile ilişkili faktörler tespit edildi.

Bulgular: Düşük grad ve yüksek grad PGISL arasında SUV maks, SUV ortalama, MTV, TLG, nüks, mortalite, genel ve hastalıkSIZ sağkalım açısından istatistiksel olarak anlamlı fark saptanmıştır. Yüksek grad PGISL'de nüks ve metastaza etki eden tüm potansiyel risk faktörlerinin (cinsiyet, yaş, site, SUV maks, SUV ortalama, MTV, TLG) tek ve çok değişkenli Cox regresyon analizinden sonra metabolik tümör parametrelerinin bir risk faktörü olmadığı görülmüştür.

Sonuç: Metabolik tümör parametreleri özellikle diffüz büyük B hücreli varyant ve primer gastrik lenfoma başta olmak üzere yüksek grade PGISL'nin prognoz tahmininde faydalı değildir. Illk izlenimler hasta yönetiminde bir rolleri olamayacağı yönündedir. Anahtar kelimeler: $18 \mathrm{~F}$-fluorodeoksiglukoz pozitron emisyon tomografi/bilgisayarlı tomografi, metabolik tümör parametreleri, primer gastrointestinal lenfoma

\section{Introduction}

Non-Hodgkin's lymphomas (NHLs) arising from tissues other than primary lymphatic sites [lymph nodes (LNs), bone marrow, spleen, thymus and Waldeyer's ring of pharyngeal lymphatics] are classified as primary extranodal lymphoma (PEL) (1). Although PEL can be seen in almost any site, gastrointestinal system (GIS) is the most frequent site (2). Thus, PEL of the GIS (PGISL) is a NHL originating from lymphatic tissues of the gastrointestinal tract. The most commonly affected site is the stomach (50-60\%) followed by the small intestine (approximately $30 \%$ ), colon, very rarely pancreas and the liver (3). Approximately $1 / 2$ to $2 / 3$ of GIS NHLs are diffuse large B-cell (DLBC) lymphomas (1).

Primary gastric lymphoma (PGL) constitutes less than $5 \%$ of all gastric neoplasms (4). It is the most common site in all PEL patients with an incidence of $4-20 \%$, and a preponderance in men over the age of 50 (5). Histologically, PGL is predominantly high-grade, DLBC or low-grade mucosa-associated lymphoid tissue (MALT), also defined as extranodal marginal zone B cell lymphoma (6). MALT lymphoma is the most common variety in PGL (7). A heterogeneous group of lymphomas including MALT, DLBC, mantle cell (MC), Burkitt and T-cell affect the small bowel (7). Primary colon lymphoma has features similar to small bowel disease with wall thickening without obstruction (8). $30-50 \%$ of patients with small bowel lymphoma initially present with an abdominal emergency (9).

The treatment of GIS lymphomas is controversial and depends on histologic type and disease stage (10). Although computed tomography (CT), 18-fluorodeoxyglucose positron emission tomography (18F-FDG PET) and 18F-FDG
PET/CT are used to stage PEL, CT is the most commonly used imaging modality for the management of patients with lymphomas (2). Most patients present with residual masses after treatment (11). A decrease in the size of a lymphomatous mass after treatment is considered as treatment response. However, a decrease in size on CT does not occur in case of fibrosis, necrosis and inflammation (11). Therefore, CT cannot differentiate residual disease from fibrosis.

18F-FDG PET is a superior imaging technique that proved its utility especially in Oncology. It can display functional alterations that precede anatomical changes. Several limitations of $\mathrm{CT}$ in lymphomas can be overcome with 18F-FDG PET. Besides, integration of CT to 18F-FDG PET creates a superior imaging modality combining anatomical detail with functional information, which results in excellent accuracy and detection capability. With all these advantages, 18 F-FDG PET/CT is being widely used in the primary staging, evaluation of treatment response, and restaging of PGISL just like other types of $\mathrm{HL}$ and many NHL lymphomas.

18F-FDG PET/CT also has a high prognostic value with respect to overall survival (OS) and disease-free survival (DFS). The semi-quantitative measurement of standardized uptake value (SUV) is an easy-to-calculate and noninvasive index reflecting 18F-FDG metabolic rate. Its assessment has additional prognostic value in early response to treatment and long-term outcome in lymphoma patients and improves the prognostic value of the test manifestly as compared to visual analysis (12). Many studies have proven the effectiveness of 18F-FDG PET/CT for primary staging, restaging and evaluation of treatment response in lymphomas (13). Despite the high incidence of PEL of the GIS, only a few studies with limited number of 
patients have been published in the literature on the use of 18F-FDG PET/CT in the management of these patients (14). Moreover, to the best of our knowledge no prior studies have been published on metabolic tumor parameters in this selective subgroup of lymphoma. This study was conducted to investigate the usefulness of metabolic tumor indices on primary staging 18F-FDG PET/CT for prognosis estimation in primary extranodal high-grade GIS lymphomas. We also studied the uptake patterns and properties of metabolic tumor parameters in different histological subtypes of PGISL.

\section{Materials and Methods}

Thirty-nine patients with PGISL (only stage 1-2 disease) from 2004 to 2015 were enrolled in this retrospective cohort study. The cases were histopathologically proven by excisional biopsy. The study was conducted at the Nuclear Medicine Department of a training and research hospital of a medical school. Primary staging 18F-FDG PET or $18 \mathrm{~F}-\mathrm{FDG}$ PET/CT have been performed for all patients prior to treatment. Disseminated nodal disease secondarily involving GIS and Hodgkin lymphoma ( $\mathrm{HL}$ ) with GIS involvement were excluded. Patients who didn't have primary staging 18F-FDG PET/CT and inadequate followup were also not included. Involvement of GIS as the predominant site with a few minor draining LNs only were also categorized as PGISL and included in the study. These patients were treated and followed up by the Medical Oncology Department of our hospital. CD20 (+) cases were treated by R-CHOP protocol (rituximab, cyclophosphamide, doxorubicin, vincristine, prednisolone), while CD20 (-) cases received $\mathrm{CHOP}$. The patients were followed by clinical history, physical examination, lactate dehydrogenase and sedimentation rate measurement, complete blood count, liver function tests, CT and/or 18F-FDG PET/CT. Information and data were obtained from clinic follow-up files, radiation therapy records, physician records of other departments at our hospital or personal contact with the patients on telephone.

\section{${ }^{18} \mathrm{~F}-\mathrm{FDG}$ PET/CT Imaging Protocol}

Patients fasted for 6 hours and their blood glucose level had to be under $150 \mathrm{mg} / \mathrm{dL}$ before the injection of an activity of 370-555 MBq of 18F-FDG according to patient's weight. Image acquisitions were performed 1 hour later with an integrated PET/CT scanner (Discovery 690-GE Healthcare). Unenhanced low dose CT and PET emission data were acquired from mid-thigh to the vertex of the skull in supine position with the arms raised over head. CT data was obtained by automated dose modulation of $120 \mathrm{kVp}$ (maximal $100 \mathrm{~mA}$ ), collimation of $64 \times 0.625 \mathrm{~mm}$, measured field of view (FOV) of $50 \mathrm{~cm}$, noise index of $20 \%$ and reconstructed to images of $0.625 \mathrm{~mm}$ transverse pixel size and $3.75 \mathrm{~mm}$ slice thickness. PET data was acquired in 3D mode with scan duration of 2 min per bed position and an axial FOV of $153 \mathrm{~mm}$. The emission data was corrected in a standardized way (random, scatter and attenuation) and iteratively reconstructed (matrix size $256 \times 256$, Fourier rebinning, VUE Point FX [3D] with 3 iterations, 18 subsets).

\section{Visual and Quantitative Interpretation}

Quantitative PET/CT parameters used in the study include maximum standardized uptake value $\left(S \cup V_{\max }\right)$, average standardized uptake value $\left(S \cup V_{\text {mean }}\right)$, metabolic tumor volume (MTV) and total lesion glycolysis (TLG). They were calculated according to a standard protocol on a dedicated workstation (Volumetrix for PET/CT and AW volume share 4.5, GE Healthcare, Waukesha, WI, USA). SUV max and $S U V_{\text {mean }}$ corrected for body weight were computed by standard methods from the activity at the most intense voxel in three-dimensional tumor region from the transaxial whole body images on attenuation-corrected PET/CT images. MTV $\left(\mathrm{cm}^{3}\right)$ was measured with semiautomatic PET analysis software using an automatic isocontour threshold method based on a theory of being greater than $42 \%$ of the $S U V_{\max }$ value within the tumor. TLG values were calculated by multiplying MTV and SUV mean. The corresponding CT scan of lesions were used as a guideline to demarcate them if their boundaries were difficult to define for the calculation of SUV $\max (15)$.

We retrospectively examined demographic characteristics, clinical findings, histology, clinical stage, response to treatment and outcome of the patients. OS was defined as the interval between diagnosis and death of any cause including ones other than the disease itself or until last follow-up. DFS was defined as the interval between diagnosis to detection of relapse or until last follow-up. Informed consent was waived due to the retrospective design of the study using records, documents and data of patients referred to our clinic for the test. Ann-Arbor staging system and definitions were used in this study. The study was approved by The study was approved by a Gülhane Training and Research Hospital Local Ethics Committee (Date: 17.02.2016, Protocol number: 40).

\section{Statistical Analysis}

The data were analyzed by IBM Corp. Released 2013. IBM SPSS Statistics for Windows, Version 22.0. Armonk, NY:IBM Corp. Number and percentage values were used for description of categorical data; while mean, median, standard deviation, minimum (min) and maximum (max) values were used for description of continuous data. Fisher's exact test was used for comparison of high-grade and low-grade PGISL in terms of sex, recurrence and mortality; the chi-square test for site; the Student-t test for age and $S U V_{\text {max; }}$ the Mann Whitney-U test for $S U V_{\text {mean }}$, MTV, TLG, OS and DFS. Univariate Cox regression analysis was used to determine factors that correlated with DFS and OS of high-grade PGISL DLBC variant. Univariate and multivariate analysis (Cox regression, Forward LR models) 
were performed for the evaluation of factors impacting recurrence. The variables having a value of $p<0.5$ were further included into multivariate analysis. ROC curve was drawn to evaluate the diagnostic value of SUV $V_{\text {max }}, S U V_{\text {mean, }}$, MTV and TLG. They were dichotomized by splitting into two groups according to ROC curve. Kaplan-Meier method with log-rank test was used to compare DFS times of metabolic tumor parameters. The study was approved by our Institutional Review Board.

\section{Results}

There were 23 DLBC lymphomas (59\%), 12 MALT lymphomas (31\%), 2 T-cell lymphomas (5\%), one MC lymphoma and one Burkitt lymphoma in the study. Totally, we had 26 high-grade PGISL (67\%) and 13 lowgrade PGISL (33\%). Twenty-eight of the patients were male $(72 \%)$ and 11 were female (28\%). Mean age of the patients was $57 \pm 15$ years (21-87 years). The site distribution amongst these 39 patients was as follows: 23 PGL (59\%) (Figure 1), 7 small bowel (18\%), 7 primary colon lymphoma (18\%), one primary pancreas lymphoma, and one primary liver lymphoma. Thirty-four out of $39(87 \%)$ cases had stage 1, while $5(13 \%)$ had stage 2 disease. Patient characteristics and demographic
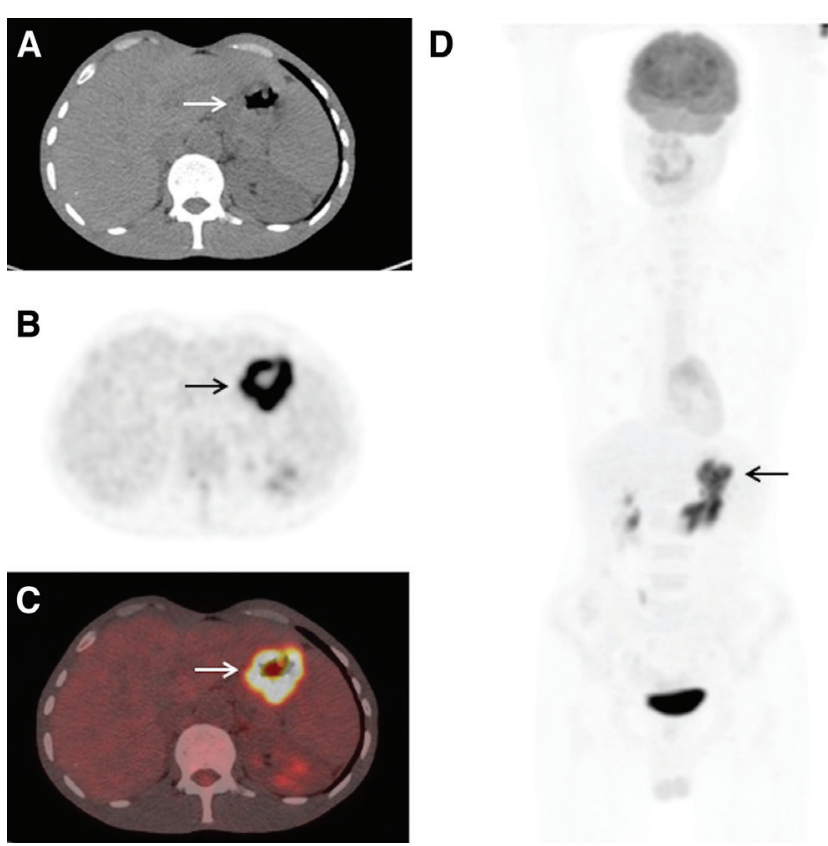

Figure 1. The SUV $V_{\max }, S U V_{m e a n}$ metabolic tumor volume and total lesion glycolysis values of a 58-year old male patient with primary gastric lymphoma diffuse large B-cell variant were 11.5, 5.2, $35 \mathrm{~cm}^{3}$ and 176 , respectively, on trans-axial computed tomography (A), positron emission tomography (B), fusion (C) and maximum intensity projection (D) images of baseline 18-fluorodeoxyglucose positron emission tomography (arrows). He responded to treatment and his disease-free survival and overall survival are 92 months findings, clinic-pathologic features and follow-up data of high-grade and low-grade PGISL are presented in Table 1 and Table 2 . There were statistically significant differences between high-grade and low-grade PGISL in terms of SUV max, SUV mean, MTV, TLG, recurrence, mortality, DFS and OS. The comparison of high-grade and low-grade PGISL features is shown in Table 3.

Univariate Cox regression was performed for all potential risk factors (sex, age, site, SUV max, SUV mean, MTV, TLG) impacting recurrence and/or metastasis (met/rec). Site, $S U V_{\text {max }}, S U V_{\text {mean, }}$ was determined as statistically significant on univariate analysis. The results of univariate Cox regression analysis are shown in Table 4. Factors with $p<0.5$ on univariate analysis (sex, age, $S U V_{\text {max }}, S U V_{\text {mean }}$, and site) were evaluated further with multivariate model. Only sex remained statistically significant on multivariate analysis $(p=0.037)$.

Within the group of patients with high-grade PGISL, 8 patients (31\%) died and 9 patients (34.5\%) developed met/rec during follow-up. Four patients died of causes other than the disease (cardiovascular events, cerebrovascular diseases, aging, etc). Four patients died of disease related reasons (extensive metastasis and related complications). OS at the 5 th year was $77 \%$, and $73 \%$ at the $10^{\text {th }}$ year. The average time to detection of met/rec was 12.6 months (4-22). DFS was $80.5 \%$ and $65 \%$ at the first and second years, respectively. ROC curve was drawn to evaluate the diagnostic value of SUV max, SUV mean, MTV and TLG in high-grade PGISL (Figure 2). Survival graphics of high-grade PGISLDLBC variant obtained by univariate Cox regression analysis was plotted. Metabolic tumor parameters were

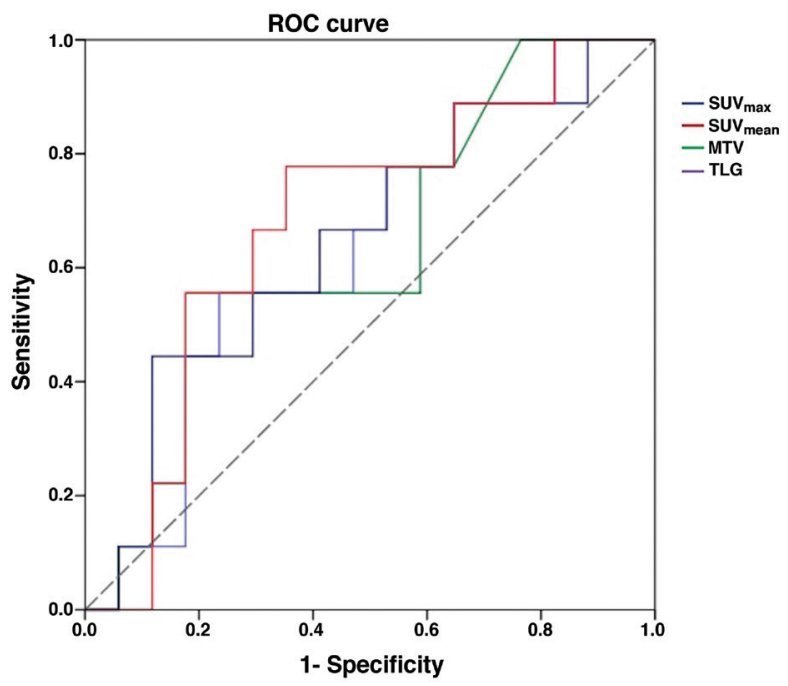

Figure 2. ROC curve of $S U V_{\text {max }}, S U V_{\text {mean }}$, metabolic tumor volume and total lesion glycolysis for high-grade primary extranodal lymphomas of the gastrointestinal system

MTV: Metabolic tumor volume, TLG: Total lesion glycolysis 
dichotomized by splitting into two groups according to ROC curve. Kaplan-Meier method with log-rank test was used to compare DFS and SUV max, SUV mean, MTV and TLG. Kaplan-Meier curves of $S U V_{\text {max }}(A), S U V_{\text {mean, }}$, (B), MTV (C), and TLG (D) with their cut-off values are illustrated in Figure 3. The sensitivity and specificity rates of SUV $V_{\text {max }} S U V_{\text {mean, }}$ MTV, and TLG according to cut-off values for high-grade PGISL are represented in Table 5.

\section{Discussion}

18F-FDG PET/CT was performed in 447 patients with $\mathrm{NHL}$ during the study period in our department. The incidence of PGISL in our study group is $8.7 \%(39 / 447)$, evidently under the rates reported in the literature due to our selective population. The peak incidence is in the $6^{\text {th- }} 7^{\text {th }}$ decades with a male predominance (16). The mean age of our group was 57 years with a male preponderance, in line with the literature. The risk of NHL is higher in men than in women, but there are certain types of NHL that are more common in women (16). However, there are no studies that have identified sex as a risk factor in the literature. We found that sex was the only factor affecting recurrence on multivariate analysis. Although female sex was the only risk factor for recurrence in our study, we attribute this finding to the insufficient sampling number,

Table 1. Demographic characteristics of patients with high-grade primary extranodal lymphomas of the gastrointestinal system, clinic-pathologic features and follow-up data

\begin{tabular}{|c|c|c|c|c|c|c|c|c|c|c|c|c|}
\hline $\begin{array}{l}\text { Patient } \\
\text { no }\end{array}$ & Age & Gender & Variant & Organ & Rec/Met & Mortality & $S_{U U V}$ max & $S_{U} V_{\text {mean }}$ & MTV & TLG & DFS & os \\
\hline 1 & 52 & $M$ & DLBC & Colon & - & - & 7.5 & 4.4 & 12.4 & 56.5 & 43 & 43 \\
\hline 2 & 75 & $M$ & DLBC & Stomach & - & - & 26.8 & 15.1 & 1211 & 18286 & 39 & 39 \\
\hline 3 & 45 & $M$ & DLBC & Pancreas & + & + & 19.9 & 13 & 112 & 1456 & 9 & 17 \\
\hline 4 & 65 & $M$ & DLBC & Jejunum & - & - & 9.9 & 4.4 & 6.9 & 30.4 & 66 & 66 \\
\hline 5 & 52 & $\mathrm{~F}$ & DLBC & Colon & + & - & 8.5 & 5.7 & 37.2 & 212 & 22 & 142 \\
\hline 6 & 72 & $\mathrm{~F}$ & DLBC & Stomach & + & + & 27.3 & 18 & 29.8 & 536.4 & 7 & 25 \\
\hline 7 & 69 & M & DLBC & Stomach & - & + & 10.1 & 5.3 & 70.2 & 372 & 34 & 34 \\
\hline 8 & 52 & $\mathrm{~F}$ & DLBC & Rectum & + & - & 14.7 & 7.1 & 13.8 & 98 & 4 & 39 \\
\hline 9 & 82 & M & DLBC & Stomach & - & + & 15 & 8.8 & 90 & 792 & 47 & 47 \\
\hline 10 & 50 & $M$ & DLBC & Ileum & - & - & 6.2 & 4.5 & 35.2 & 158.4 & 27 & 27 \\
\hline 11 & 47 & M & DLBC & Stomach & - & - & 9.9 & 5.7 & 96 & 547.2 & 110 & 110 \\
\hline 12 & 35 & M & DLBC & Stomach & - & - & 39.8 & 21 & 144 & 3024 & 17 & 17 \\
\hline 13 & 61 & $\mathrm{~F}$ & DLBC & Stomach & - & + & 20.2 & 11.15 & 32.3 & 360.1 & 70 & 70 \\
\hline 14 & 56 & M & DLBC & Stomach & - & + & 15.2 & 8.4 & 50.5 & 424.2 & 123 & 123 \\
\hline 15 & 46 & $\mathrm{M}$ & DLBC & Stomach & - & - & 16.3 & 9 & 75 & 675 & 110 & 110 \\
\hline 16 & 72 & M & DLBC & Liver & + & + & 14.4 & 7.1 & 79 & 560.9 & 13 & 21 \\
\hline 17 & 51 & $F$ & DLBC & Stomach & + & - & 24.4 & 14.8 & 98 & 1450 & 22 & 38 \\
\hline 18 & 62 & $\mathrm{~F}$ & DLBC & Colon & - & - & 16.5 & 10.4 & 23 & 239.2 & 21 & 21 \\
\hline 19 & 73 & M & DLBC & Stomach & - & - & 11.8 & 6.7 & 23.7 & 158.8 & 43 & 43 \\
\hline 20 & 50 & $M$ & DLBC & Stomach & - & - & 27 & 17.7 & 82.6 & 1462 & 75 & 75 \\
\hline 21 & 56 & M & DLBC & Jejunum & + & - & 22 & 13.4 & 59.5 & 797.3 & 11 & 35 \\
\hline 22 & 58 & M & DLBC & Stomach & - & - & 11.5 & 5.2 & 35 & 176 & 92 & 92 \\
\hline 23 & 61 & $\mathrm{~F}$ & DLBC & Stomach & + & + & 25.7 & 15.3 & 107.2 & 1648 & 17 & 33 \\
\hline 24 & 87 & $M$ & T-cell & Colon & - & - & 7.3 & 4.1 & 14.4 & 59 & 6 & 6 \\
\hline 25 & 64 & M & T-cell & Ileum & - & - & 13.9 & 8.6 & 23.5 & 202.1 & 43 & 43 \\
\hline 26 & 21 & $M$ & Burkitt & Colon & + & - & 10.7 & 5.3 & 468 & 2480 & 7 & 32 \\
\hline
\end{tabular}

Rec: Recurrence, M: Male, F: Female, DLBC: Diffuse large B-cell, MTV: Metabolic tumor volume, TLG: Total lesion glycolysis, DFS: Disease-free survival, OS: Overall survival 
and thus believe this finding might not be clinically important.

Gastrointestinal tract is the most common extranodal site of $\mathrm{NHL}(17)$. The stomach is the most frequently involved (60-74\% of cases) site, followed by the duodenum and small bowel (10-20\%), ileocecal region (7-10\%), and colon
$(<10 \%)(18)$. Our results are consistent with these reports, except that the colon was affected in a greater percentage of patients (equal to small intestine involvement) than previous studies. The stomach is the most common site of primary GIS lymphoma, and gastric MALT lymphoma is the most common type (7). In our study, 39\% of gastric

Table 2. Demographic characteristics of patients with low-grade primary extranodal lymphomas of the gastrointestinal system, clinic-pathologic features and follow-up data

\begin{tabular}{|c|c|c|c|c|c|c|c|c|c|c|c|c|}
\hline $\begin{array}{l}\text { Patient } \\
\text { no }\end{array}$ & Age & Gender & Variant & Organ & Rec/Met & Ex & SUV $_{\text {max }}$ & $S U V_{\text {mean }}$ & MTV & TLG & DFS & OS \\
\hline 1 & 64 & $F$ & MALT & Stomach & - & - & 5.2 & 2.7 & 57 & 153.9 & 62 & 62 \\
\hline 2 & 25 & $M$ & MALT & Duodenum & - & - & 6.5 & 4.1 & 30.8 & 126.3 & 121 & 121 \\
\hline 3 & 65 & $\mathrm{~F}$ & MALT & Stomach & - & - & 10.2 & 6.1 & 135.2 & 824.7 & 88 & 88 \\
\hline 4 & 33 & $\mathrm{M}$ & MALT & Stomach & - & - & 3.3 & 2 & 17.9 & 36.5 & 33 & 33 \\
\hline 5 & 57 & $M$ & MALT & Ileum & - & - & 7.6 & 4 & 18.2 & 72.8 & 61 & 61 \\
\hline 6 & 49 & $M$ & MALT & Stomach & - & - & 3.65 & 2.8 & 8.6 & 24.1 & 57 & 57 \\
\hline 7 & 77 & $M$ & MALT & Stomach & - & - & 3 & 2.7 & 7.9 & 21.25 & 161 & 161 \\
\hline 8 & 39 & $M$ & MALT & Stomach & - & - & 5.4 & 2.8 & 27.8 & 77.8 & 119 & 119 \\
\hline 9 & 57 & $\mathrm{~F}$ & MALT & Stomach & - & - & 6 & 2.9 & 63.6 & 184.4 & 53 & 53 \\
\hline 10 & 55 & $\mathrm{M}$ & MALT & Stomach & - & - & 7.5 & 4.3 & 16 & 68.8 & 70 & 70 \\
\hline 11 & 80 & $F$ & MALT & Stomach & - & - & 5.3 & 2.95 & 10 & 29.5 & 59 & 59 \\
\hline 12 & 62 & $M$ & MALT & Jejunum & - & - & 5.3 & 3.2 & 29 & 92.8 & 40 & 40 \\
\hline 13 & 55 & $M$ & $M C$ & Colon & - & - & 4.6 & 2.2 & 18.3 & 40.3 & 60 & 60 \\
\hline
\end{tabular}

Rec: Recurrence, M: Male, F: Female, MC: Mantle cell, MALT: Mucosa-associated lymphoid tissue, MTV: Metabolic tumor volume, TLG: Total lesion glycolysis, DFS: Disease-free survival, OS: Overall survival

Table 3. Comparison of high-grade and low-grade primary extranodal lymphomas of the gastrointestinal system in terms of patient characteristics, follow-up data and metabolic tumor parameters

\begin{tabular}{|c|c|c|c|c|}
\hline Variables & & Low-grade PGISL & High-grade PGISL & Significance ( $p$ value) \\
\hline Sex & $\begin{array}{l}\text { Male } \\
\text { Female }\end{array}$ & $\begin{array}{l}9(69 \%) \\
4(31 \%)\end{array}$ & $\begin{array}{l}19(73 \%) \\
7(27 \%)\end{array}$ & 0.542 \\
\hline Mean age (years) & & $55 \pm 16$ & $58 \pm 14.5$ & 0.730 \\
\hline Mean SUV $\max$ & & $5.6 \pm 2$ & $16.75 \pm 8$ & 0.038 \\
\hline Mean $S U V_{\text {mean }}$ & & $3.25 \pm 1$ & $9.75 \pm 4.8$ & 0.024 \\
\hline Mean MTV $\left(\mathrm{cm}^{3}\right)$ & & 34 (MD: 18) & 117 (MD: 55.5) & $<0.001$ \\
\hline Mean TLG & & 135 (MD: 72.8) & 1404 (MD: 487) & $<0.001$ \\
\hline Recurrence (+) & & 0 & $9(34.5 \%)$ & 0.018 \\
\hline Mortality (+) & & 0 & $8(31 \%)$ & 0.035 \\
\hline Mean DFS (months) & & $75.5 \pm 36.8$ & $41.5 \pm 35.5$ & 0.003 \\
\hline Organ & $\begin{array}{l}\text { Colon } \\
\text { Stomach } \\
\text { Intestine }\end{array}$ & $\begin{array}{l}1(8 \%) \\
9(69 \%) \\
3(23 \%)\end{array}$ & $\begin{array}{l}6(23 \%) \\
14(54 \%) \\
4(15 \%)\end{array}$ & 0.596 \\
\hline Mean OS (months) & & $75.5 \pm 36.8$ & $52 \pm 36$ & 0.002 \\
\hline
\end{tabular}

MD: Median value, PGISL: Primary extranodal lymphomas of the gastrointestinal system, MTV: Metabolic tumor volume, TLG: Total lesion glycolysis, DFS: Disease-free survival, OS: Overall survival 
Table 4. Univariate Cox regression analysis of high-grade primary extranodal lymphomas of the gastrointestinal system diffuse large B-cell variant

\begin{tabular}{|c|c|c|c|c|}
\hline \multirow[t]{2}{*}{ Factors } & \multirow{2}{*}{$\begin{array}{l}\text { Significance } \\
\text { ( } p \text { value) }\end{array}$} & \multirow{2}{*}{$\begin{array}{l}\text { Hazard } \\
\text { ratio }\end{array}$} & \multicolumn{2}{|c|}{$\begin{array}{l}95 \% \mathrm{Cl} \text { for Hazard } \\
\text { ratio }\end{array}$} \\
\hline & & & Lower & Upper \\
\hline Sex* & 0.063 & 0.287 & 0.077 & 1.071 \\
\hline Age & 0.460 & 0.982 & 0.938 & 1.030 \\
\hline$S U V_{\max }$ & 0.026 & 1.073 & 1.009 & 1.141 \\
\hline$S U V_{\text {mean }}$ & 0.020 & 1.141 & 1.021 & 1.275 \\
\hline MTV & 0.719 & 1,000 & 0.998 & 1.003 \\
\hline TLG & 0.973 & 1.000 & 1.000 & 1.000 \\
\hline Organ** & 0.034 & Reference & & \\
\hline Stomach & 0.040 & 0.186 & 0.037 & 0.929 \\
\hline Intestine & 0.228 & 4.484 & 0.392 & 51.330 \\
\hline
\end{tabular}

Reference groups: ${ }^{\star}$ Male sex, ${ }^{* *}$ Colon, MTV: Metabolic tumor volume, TLG: Total lesion glycolysis, Cl: Confidence interval lymphomas were MALT type while $61 \%$ were DLBC variant. Our incidence of gastric DLBC was markedly higher than gastric MALToma. This result is in contrast to the literature. MALT, DLBC, MC, Burkitt and T cell can all be seen in the small bowel and colon. The most common variant was DLBC (59\%) in our patients followed by MALT (31\%). These

Table 5. Cut-off value, sensitivity and specificity rates of SUV $_{\text {max }}$, SUV $_{\text {mean }}$, metabolic tumor volume and total lesion glycolysis in high-grade primary extranodal lymphomas of the gastrointestinal system

\begin{tabular}{llll}
\hline Factors & Cut-off value & $\begin{array}{l}\text { Sensitivity } \\
(\%)\end{array}$ & Specificity (\%) \\
\hline SUV $_{\text {max }}$ & 18.2 & 89 & 62 \\
SUV $_{\text {mean }}$ & 12.1 & 100 & 52 \\
MTV $\left(\mathrm{cm}^{3}\right)$ & 97 & 89 & 48 \\
TLG & 487 & 78 & 76 \\
\hline
\end{tabular}

MTV: Metabolic tumor volume, TLG: Total lesion glycolysis
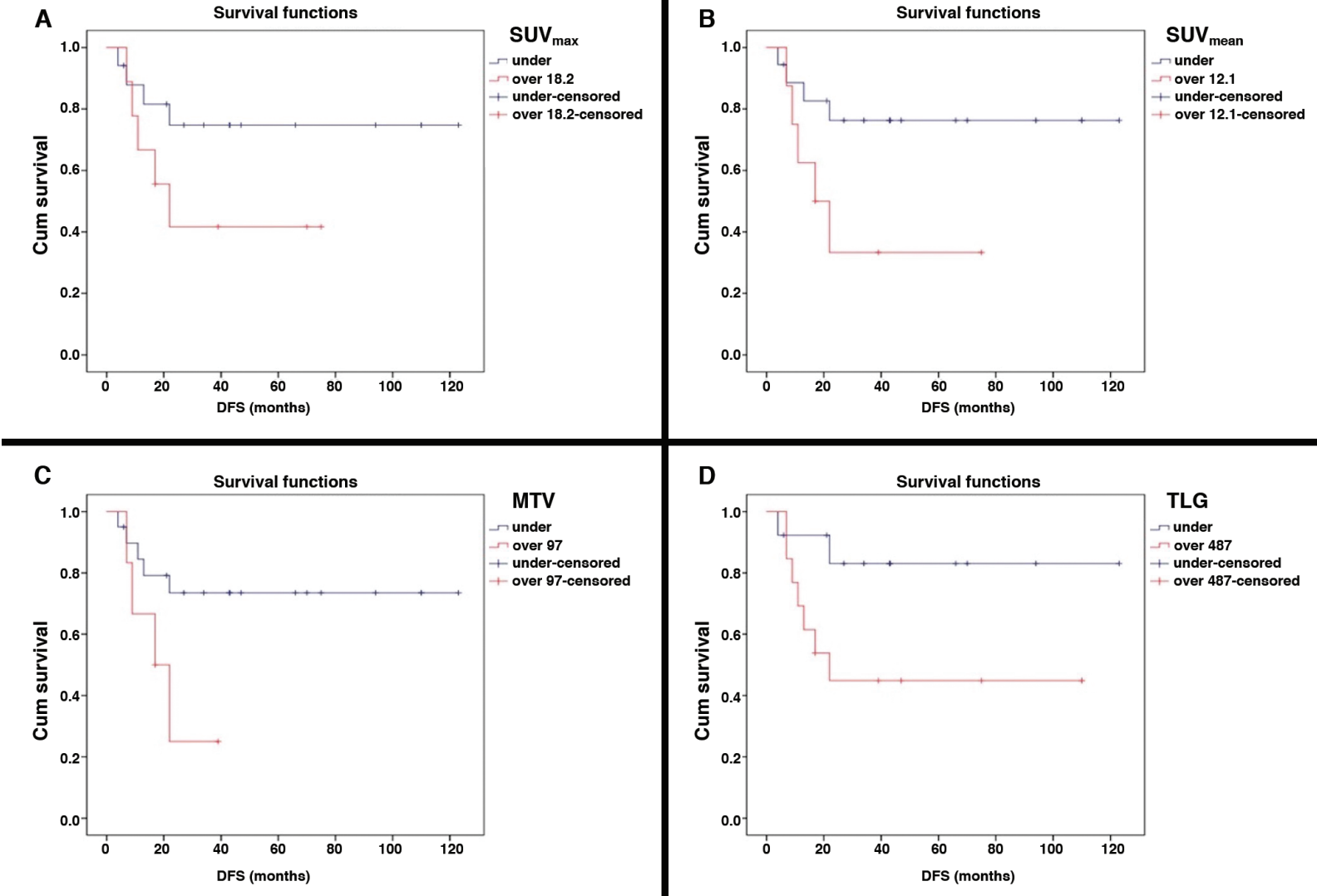

Figure 3. Survival graphic of high-grade primary extranodal lymphomas of the gastrointestinal system diffuse large B-cell variant obtained by univariate

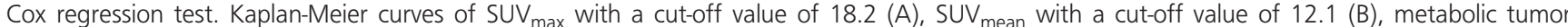
volume with a cut-off value of $97 \mathrm{~cm}^{3}(C)$, total lesion glycolysis with a cut-off value of 487 (D) for high-grade primary extranodal lymphomas of the gastrointestinal system

MTV: Metabolic tumor volume, TLG: Total lesion glycolysis, DFS: Disease-free survival 
findings are also completely in agreement with previous reports.

Primary hepatic lymphoma (PHL) is very rare and up to date, only about 300 cases were published in the literature. Of all PELs, only $0.4 \%$ occurs in the liver (9). The most common variant in the liver is DLBC, accounting in one study for $71 \%$ of all cases (19). Our sole PHL patient was a DLBC subtype with poor prognosis (recurred at the 13th, died at the 21 st month). Primary pancreatic lymphoma (PPL) is defined as an extranodal lymphoma arising in the pancreas with the bulk of the tumor localized to the pancreas. PPL is a very rare disease, accounting for less than $0.5 \%$ of pancreatic tumors (20). The only case with PPL in our study was a DLBC variant and his clinical course was fatal with high metabolic parameters (recurred at the 9th, died at the 17th month).

There is a correlation between 18F-FDG uptake and histologic grade of lymphoma, since rapidly proliferating lymphoma cells have a high metabolic rate and aggressive subtypes of NHL take up high levels of 18F-FDG (21). The 18F-FDG PET imaging in our study showed that high-grade PGISL had high 18F-FDG activity as confirmed with high metabolic tumor parameters. Particularly, DLBC variants exhibited usually high 18F-FDG accumulation. Although low-grade PGISL lesions were identified with difficulty especially in MALT lymphoma, MALT types had variable (usually moderate) uptake in this study. Jerusalem et al. (22) reported that low-grade NHLs such as follicular lymphoma and MC lymphoma do not demonstrate 18F-FDG-avidity to the same degree with high-grade lymphomas, but they are still 18F-FDG-avid enough to be detected. There was a significant difference in terms of $S U V_{\text {max }}, S U V_{\text {mean, }}$, MTV and TLG between high-grade and low-grade PGISL in our patients $(p=0.038, p=0.024, p<0.001, p<0.001$, respectively).

The majority of patients with MC present with advancedstage disease and often have extranodal sites. These patients have a poor prognosis with a median survival of 3 to 4 years (23). One patient with MC lymphoma in this study accumulated mild 18F-FDG and had a good prognosis, nevertheless, our patient had stage 1 disease. MALT lymphoma is the third most common NHL following DLBC and follicular lymphoma (24). Most studies report that MALT lymphomas demonstrate moderate to high 18F-FDG accumulation while a few studies with limited number of patients claim that 18F-FDG PET imaging is unreliable in case of primary extranodal MALT lymphoma (25). We detected usually moderate uptake and no recurrence or death in our cases with MALT Iymphoma. Burkitt lymphoma is a highly aggressive B-cell NHL. There was only one patient with Burkitt type among our cases. The 18F-FDG uptake was high in that patient with increased metabolic tumor parameters, and the tumor recurred at 7 months. T-cell lymphomas are generally aggressive neoplasms. Two of our cases with T-cell variant had a favorable prognosis with moderate 18F-FDG uptake. Six gastric DLBC, one PHL and one PPL were responsible for deaths. We observed complete remission in 26 patients (13/26 in the high-grade group, all patients in the low-grade group). In our study group, DFS was identified as $77 \%$ and OS as $79.5 \%$ with a mean follow-up of 65 months (6-161). These results are in agreement with other studies in the literature.

Quantitative metabolic parameters (SUV max, SUV mean, MTV, TLG) obtained from initial staging PET/CT has been used in prognosis estimation and evaluation of treatment response for many cancers and lymphomas. Tumor cells utilize glucose at a higher metabolic rate as displayed by abnormal 18F-FDG uptake. SUV measures this consumption rate that correlates with cellular metabolism (26). SUV $V_{\max }$ is the first one of metabolic tumor parameters, which represents the highest $18 \mathrm{~F}-\mathrm{FDG}$ uptake within the tumor volume. SUV $\mathrm{V}_{\text {mean }}$ represents the average activity in a tumor burden. Recently, volume-based metabolic parameters (MTV and TLG) have been used to detect recurrent disease to the best of our knowledge, the literature lacks any study pertaining to the use of these metabolic factors for prognosis estimation in high-grade PGISL.

Although a study specifically on this subject has not been conducted, similar studies with $S U V_{\text {mean }}$ has been previously reported. Most studies investigated metabolic tumor parameters for different sites or unique variants and aimed to evaluate them in treatment. Esfahani et al. (27) stated TLG as the most significant parameter for predicting detection of recurrence in DLBC on initial and interim PET. Gallicchio et al. (28) reported that quantitative parameters were helpful in the management of patients with DLBC. Recently, TLG emerged as a remarkable predictor in many cancers and lymphomas, since it contributes to patient management by assessing both tumor volume and metabolism. Ceriani et al. (29) suggested TLG as the most powerful predictor on baseline PET/CT in DLBC. However, there are no studies on these parameters in PGISL. To the best of our knowledge, our study is the first one in which the prognosis of highgrade PGISL was predicted by these metabolic indicators.

Previously reported studies on PGISL are usually focused on evaluating response to treatment by $S U V_{\max }$ alone. Phongkitkarun et al. (15) reported that $S U V_{\max }$ plays an important role in the evaluation of treatment response. Kumar et al. (2) identified high $S U V_{\max }$ as a strong predictor of recurrence after completion of therapy. We aimed to investigate the efficacy of all metabolic tumor parameters for predicting prognosis in high-grade PGISL. After evaluation of all potential risk factors effecting met/rec with univariate Cox regression analysis and multivariate model, none of the study parameters were detected to have a statistically significant correlation with DFS in our study. Analysis of the diagnostic value of these parameters by ROC curve determined high sensitivity rates for $S U V_{\text {max }}, S U V_{\text {mean, }}$ MTV and a 
high specificity rate for TLG with the selected cut-off values (487 for TLG). The results indicate that highgrade PGISL, especially DLBC subtype and PGL, tend to have high metabolic parameters indirectly reflecting high mitotic activity of tumor cells. This particularity is perhaps responsible for responding well to treatment. In other words, first results indicate that metabolic tumor parameters are not prognostic in high-grade PGISL despite their high values.

\section{Conclusion}

Metabolic tumor parameters are not predictive markers in primary high-grade gastrointestinal lymphomas, especially in DLBC variant and PGL. The findings suggest they will not play a role in patient management. Female sex was identified as the single risk factor for recurrence.

\section{Ethics}

Ethics Committee Approval: The study was approved by Gülhane Training and Research Hospital Local Ethics Committee (Date: 17.02.2016, Protocol number: 40).

Informed Consent: Consent form was filled out by all participants. Informed consent was waived due to the retrospective design of the study using records, documents and data of patients referred to our clinic for the test.

Peer-review: Externally peer-reviewed.

\section{Authorship Contributions}

Surgical and Medical Practices: E.A., K.O., S.I., Concept: E.A., K.O., N.A., Design: E.A., K.O., M.K., Data Collection or Processing: E.A., K.O., S.I. Analysis or Interpretation: E.A., C.H., T.T., Literature Search: E.A., K.O., S.I., Ş.Ö., Writing: E.A., K.O., S.i.

Conflict of Interest: The authors declared that there is no conflict of interest regarding the publication of this paper.

Financial Disclosure: The authors declared that this study received no financial support.

\section{References}

1. Kashyap R, Rai Mittal B, Manohar K, Balasubramanian Harisankar CN, Bhattacharya A, Singh B, Malhotra P, Varma S. Extranodal manifestations of lymphoma on [18F]FDG PET/CT: a pictorial essay. Cancer Imaging 2011;11:166-174.

2. Kumar R, Xiu Y, Potenta S, Mavi A, Zhuang H, Yu JQ, Dhurairaj T, Dadparvar S, Alavi A. 18F-FDG PET for evaluation of the treatment response in patients with gastrointestinal tract lymphomas. J Nucl Med 2004;45:1796-1803.

3. Koniaris LG, Drugas G, Katzman PJ, Salloum R. Management of gastrointestinal lymphoma. J Am Coll Surg 2003;197:127-141.

4. Al-Akwaa AM, Siddiqui N, Al-Mofleh IA. Primary gastric lymphoma. World J Gastroenterol 2004;10:5-11.

5. Radan L, Fischer D, Bar-Shalom R, Dann EJ, Epelbaum R, Haim $N$, Gaitini $D$, Israel O. FDG avidity and PET/CT patterns in primary gastric lymphoma. Eur J Nucl Med Mol Imaging 2008;35:14241430.
6. d'Amore F, Brincker H, Grønbaek K, Thorling K, Pedersen M, Jensen MK, Andersen E, Pedersen NT, Mortensen LS. Non-Hodgkin's lymphoma of the gastrointestinal tract: a population-based analysis of incidence, geographic distribution, clinicopathological presentation features and prognosis. Danish Lymphoma Study Group. J Clin Oncol 1994;12:1673-1684.

7. Dodd GD. Lymphoma of the hollow abdominal viscera. Radiol Clin North Am 1990;28:771-783.

8. Gollub MJ. Imaging of gastrointestinal lymphoma. Radiol Clin North Am 2008;46:287-312.

9. Freeman C, Berg JW, Cutler SJ. Occurrence and prognosis of extranodal lymphomas. Cancer 1972;29:252-260.

10. Zucca E, Cavalli F. Extranodal lymphomas. Ann Oncol. 2000;11(Suppl 3):219-222.

11. Weihrauch MR, Dietlein M, Schicha H, Diehl V, Tesch H. Prognostic significance of 18F-fluorodeoxyglucose positron emission tomography in lymphoma. Leuk Lymphoma 2003;44:15-22.

12. Schrepfer T, Haerle SK, Strobel K, Schaefer N, Hälg RA, Huber GF. The value of (18)F-fluorodeoxyglucose positron emission tomography/ computed tomography for staging of primary extranodal head and neck lymphomas. Laryngoscope 2010;120:937-944.

13. Spaepen K, Stroobants S, Verhoef G, Mortelmans L. Positron emission tomography with [18F]FDG for therapy response monitoring in lymphoma patients. Eur J Nucl Med Mol Imaging 2003;30(Suppl 1):97-105

14. Hoffmann M, Vogelsang H, Kletter K, Zettinig G, Chott A, Raderer M. 18F-fluoro-deoxy-glucose positron emission tomography (18F-FDG PET) for assessment of enteropathy-type T cell lymphoma. Gut 2003;52:347-351.

15. Phongkitkarun S, Varavithya V, Kazama T, Faria SC, Mar MV, Podoloff DA, Macapinlac HA. Lymphomatous involvement of gastrointestinal tract: evaluation by positron emission tomography with (18) F-fluorodeoxyglucose. World J Gastroenterol 2005;11:7284-7289.

16. Ezzat AA, Ibrahim EM, El Weshi AN, Khafaga YM, AlJurf $M$, Martin JM, Ajarim DS, Bazarbashi SN, Stuart RK, Zucca E Localized non-Hodgkin's lymphoma of Waldeyer's ring: clinical features, management, and prognosis of 130 adult patients. Head Neck 2001:23:547-558

17. Amer $\mathbf{M H}$, el-Akkad S. Gastrointestinal lymphoma in adults: clinical features and management of 300 cases. Gastroenterology 1994; 106:846-858.

18. Kolve ME, Fischbach W, Wilhelm M. Primary gastric non-Hodgkin's lymphoma: requirements for diagnosis and staging. Recent Results Cancer Res 2000;156:63-68.

19. Bronowicki JP, Bineau C, Feugier P, Hermine O, Brousse N, Oberti F, Rousselet MC, Dharancy S, Gaulard P, Flejou JF, Cazals-Hatem D, Labouyrie E. Primary lymphoma of the liver: clinical-pathological features and relationship with HCV infection in French patients. Hepatology 2003;37:781-787.

20. Yoon WJ, Yoon YB, Kim YJ, Ryu JK, Kim YT. Primary pancreatic lymphoma in Korea-a single center experience. J Korean Med Sci 2010;25:536-540.

21. Yi JH, Kim SJ, Choi JY, Ko YH, Kim BT, Kim WS. 18F-FDG uptake and its clinical relevance in primary gastric lymphoma. Hematol Oncol 2010;28:57-61.

22. Jerusalem G, Beguin Y, Najjar F, Hustinx R, Fassotte MF, Rigo P, Fillet G. Positron emission tomography (PET) with 18F-fluorodeoxyglucose (18F-FDG) for the staging of low-grade non-Hodgkin's lymphoma (NHL). Ann Oncol 2001;12:825-830.

23. Alavi A, Shrikanthan S, Aydin A, Talanow R, Schuster S Fluorodeoxyglucose positron-emission tomography findings in mantle cell lymphoma. Clin Lymphoma Myeloma Leuk 2011;11:261266.

24. Cavalli F, Isaacson PG, Gascoyne RD, Zucca E. MALT Lymphomas. Hematology Am Soc Hematol Educ Program 2001:241-258.

25. Beal KP, Yeung HW, Yahalom J. FDG PET scanning for detection and staging of extranodal marginal zone lymphomas of the MALT type: a report of 42 cases. Ann Oncol 2005; 16:473-480. 
26. Song MK, Chung JS, Lee JJ, Jeong SY, Lee SM, Hong JS, Chong A, Moon JH, Kim JH, Lee SM, Kim SJ, Shin HJ. Metabolic tumor volume by positron emission tomography/computed tomography as a clinical parameter to determine therapeutic modality for early stage Hodgkin's lymphoma. Cancer Sci 2013;104:16561661.

27. Esfahani SA, Heidari P, Halpern EF, Hochberg EP, Palmer EL, Mahmood U. Baseline total lesion glycolysis measured with (18)F-FDG PET/ $\mathrm{CT}$ as a predictor of progression-free survival in diffuse large B-cell lymphoma: a pilot study. Am J Nucl Med Mol Imaging 2013;3:272281.
28. Gallicchio R, Mansueto $G$, Simeon $V$, Nardelli A, Guariglia $R$, Capacchione D, Soscia E, Pedicini P, Gattozzi D, Musto P, Storto G. F-18 FDG PET/CT quantization parameters as predictors of outcome in patients with diffuse large B-cell lymphoma. Eur J Haematol 2014;92:382-389.

29. Ceriani L, Martelli M, Zinzani PL, Ferreri AJ, Botto B, Stelitano C, Gotti M, Cabras MG, Rigacci L, Gargantini L, Merli F, Pinotti G, Mannina D, Luminari S, Stathis A, Russo E, Cavalli F, Giovanella L, Johnson PW, Zucca E. Utility of baseline 18FDG PET/CT functional parameters in defining prognosis of primary mediastinal (thymic) large B-cell lymphoma. Blood 2015;126:950-956. 